\title{
LUKASZ MARZEC
}

Uniwersytet Jagielloński

\section{PRAWO RZYMSKIE - SKŁADNIK ANGIELSKIEJ DOKTRYNY I PRAKTYKI PRAWA NARODÓW?}

1. Rzetelna i kompletna analiza historyczna wplywów prawa rzymskiego w angielskim systemie prawnym stanowi dla współczesnej romanistyki światowej kwestię równie kontrowersyjną co niewystarczająco zbadaną. Jeden z czołowych brytyjskich historyków prawa, William Holdsworth, wyraził na początku ubiegłego stulecia przekonanie', iż najlepszym opracowaniem tego zagadnienia jest w dalszym ciągu - powstałe w połowie XVII wieku dzieło Artura Ducka $^{2}$ De Usu et Authoritate Juris Civilis Romanorum in Dominiis Principum Christianorum. Miniony wiek również nie wniósł do sprawy wiele światła, jakkolwiek należy zaakcentować pewne wysitki doktryny brytyjskiej, amerykańskiej i niemieckiej, zwracające przynajmniej uwagę na potencjalne rzymskie korzenie wielu insty-

\footnotetext{
' W. HoldsworTh, A History of English Law, V, London, 1973, s. 24

${ }^{2}$ Artur Duck pozostaje wciąż rzadko cytowanym autorem. W Polsce pisał o nim J. SONDEL, Artur Duck - niedoceniany poprzednik Savigny'ego i jego poglady na role prawa rzymskiego w Polsce, "ZN UJ. Prace Prawnicze» 97 (1982), s. 69-85. Za granicą natomiast N. HoRN, Römisches Recht als gemeineuropäisches Recht bei Arthur Duck, [w:] Studien zur europäischen Rechtsgeschichte, Frankfurt 1972, s. 170. Całościowa analiza jego dzieła, a także aktywnie prowadzonej działalności politycznej nie powstała do tej pory.
} 
tucji prawa angielskiego ${ }^{3}$. Całkowite wyjaśnienie tego zagadnienia jest w dalszym ciągu niewątpliwie kwestią przyszłości. Jednak obecny stan badań prowadzonych w różnych ośrodkach akademickich pozwala na śmiałe wyrażenie tezy, iż treści zaczerpnięte $z$ prawa rzymskiego oddziaływały $\mathrm{z}$ różnym natężeniem na szereg dziedzin prawa angielskiego. Należy nadmienić, iż metodologia takich badań różni się zasadniczo w porównaniu do dociekań nad recepcją prawa rzymskiego w systemach kontynentalnych. Stopień trudności, a także charakterystyczne dla prawa precedensowego ukrycie i rozproszenie, czyni poszukiwania potencjalnych wpływów romanistycznych w setkach tomów brytyjskich Reports i Records niezwykle uciążliwymi ${ }^{4}$. Ponadto, bardzo istotne są kwalifikacje prowadzącego badania porównawcze, a zwłaszcza rzadko spotykana u historyków prawa szczegółowa biegłość poruszania się w zakresie obu konkurencyjnych systemów prawnych.

Poczynając od początku panowania dynastii Tudorów, w Anglii stopniowo rosną wpływy prawa rzymskiego, które w okresie rządów Jakuba I Stuarta urosło do roli groźnego konkurenta common law. Od samego początku jednym z pól szczególnej aktywności angielskich civil lawyers (których główną podstawą wykształcenia był doktorat z prawa rzymskiego, a nie typowe dla Anglii wyszkolenie zawodowe w czterech Inns of Court) była dyplomacja i pączkujące dopiero w XVI i XVII wieku prawo narodów. Pozostaje faktem, iż to właśnie jurysprudencja brytyjska wywarła znaczący wpływ na ukształtowanie i rozwój tej gałęzi prawa. Mocarstwowa pozycja tego kraju w świecie, jak również rola największego imperium kolo-

\footnotetext{
${ }^{3}$ Przegląd literatury tematu podaje M. ReimanN, Who is afraid of the Civil Law? Kontinentaleuropäisches Recht und Common Law im Spiegel der englischen Literatur seit 1500, «Zeitschrift für Neuere Rechtsgeschichte» 21 (1999), s. 357-381.

${ }^{4}$ Pewnym ułatwieniem będzie tu $\mathrm{z}$ pewnością tworzone przez niektóre uniwersytety systematyczne komputerowe bazy danych starych zbiorów precedensów sądowych. Przykładem może tu być projekt ECCE prowadzony przez T. Hasketta z Uniwersytetu w Toronto, gdzie przetworzono w bazy danych wczesne orzecznictwo Sądu Kanclerskiego. Por. na ten temat T. HASKETT, The Medieval English Court of Chancery, «Law and History Review Fall» 14 (1996), s. 245-313.
} 
nialnego świata, wpłynęła na doraźną konieczność wykształcenia elementarnych zasad stosunków międzynarodowych. To właśnie Anglicy w dużym stopniu przyczynili się do rozwoju teorii prawa narodów: dzieła Gentilisa ${ }^{5}$, Zouche'a, Westlake'a, Phillimore'a czy Maine'a do dnia dzisiejszego stanowią jej kanon. Analiza dzieł tychże autorów wskazuje na ich wręcz nabożny stosunek do prawa rzymskiego, co wydaje się sprzeczne $\mathrm{z}$ rozpowszechnionymi opiniami o rzekomym oporze Anglików wobec tego prawa. Co więcej, jak wskazuje nawet dość pobieżny przegląd sporów międzynarodowych, w których Wielka Brytania (w XIX i XX wieku) występowała jako strona bądź arbiter, bardzo chętnie powoływała się ona na autorytet prawa rzymskiego poszukując w nim oparcia lub kontrargumentu. Przykłady takiego postępowania pochodzą zresztą nawet z czasów współczesnych. Anglia dość szybko zorientowała się, iż nie sposób utrzymywać międzynarodowych stosunków dyplomatycznych bez wykwalifikowanej kadry prawników, których podstawowym warsztatem pracy było prawo rzymskie. Angielska służba zagraniczna była świadoma bolesnej dla niej odmienności myślenia prawników kontynentu i Wysp, dbała zatem o zapewnienie właściwej obsady personalnej. Podczas organizacji misji dyplomatycznej do Danii w 1600 r. jej szef Richard Bancroft zażądał dołączenia do składu ekipy wykwalifikowanego civil lawyer. Na propozycję akcesu doktora teologii odparł, iż wersy ze św. Pawła zna na pamięć, a sam wolałby jednak dobrego Bartolistę ${ }^{6}$. Często także cywiliści doradzali Tajnej Radzie, o czym będzie jeszcze mowa, w zakresie zawierania traktatów, stosunków międzynarodowych, udzielania azylów politycznych i innych ${ }^{7}$. Nie należy zapominać, iż międzynarodowym językiem negocjacyjnym była łacina, a nikt bardziej niż specjaliści

\footnotetext{
${ }^{5} \mathrm{Z}$ oczywistym zastrzeżeniem biograficznym, iż Anglia była dla Gentilisa miejscem pracy, a nie pochodzenia.

'I can say some part of St. Paul's Episles by heart, but that will not serve to encounter in this case so much as with Bartolus; por. B. LEVACK, The Civil Lawyers in England, 1603-1641; a political study, Oxford, 1973, s. 26-27

' B. Levack, The Civil Lawyers, cit., s. 26-27.
} 
od prawa rzymskiego nie znał lepiej pełnej zasadzek lingwistycznych terminologii prawniczej. Corpus Iuris Civilis stanowiło najlepsze źródło stosowane w praktyce międzynarodowej jako zawierające regulacje typowe dziś dla rozwiniętego prawa międzynarodowego. Problematyka traktatów, misji dyplomatycznych, niewoli wojennej, prowadzenia sporów, wojen i wiele innych, w naturalny sposób wpisywała się w rodzącą się gałąź prawa.

2. Ujmując zagadnienie chronologicznie, należy rozpocząć od dwóch szesnastowiecznych teoretyków prawa narodów, Alberigo Gentilego i Richarda Zouche'a. Gentili nie był Anglikiem, jakkolwiek całe jego zawodowe życie związane jest z Anglią. Wykształcony w Perugii, uzyskał doktorat w 1572 r. W 1580 r. przybył do Anglii jako uchodźca religijny. Osiadł w Oxfordzie jako wykładowca, oddając się pracy dydaktycznej i publikacji traktatów naukowych, z których najgłośniejsze to De Jure Belli, De Legationibus, oraz Advocationis Hispanicae duo libri. Na Wyspach uzyskał znaczne poważanie i rozgłos, o czym świadczyć może sprawa konsultacji, jakiej udzielit Tajnej Radzie (Privy Council) w związku ze sprawą Mendozy. Ponieważ opierała się ona o autorytet prawa rzymskiego, warto w tym miejscu krótko o niej wspomnieć.

W 1584 r. ambasador hiszpański przy dworze królowej Elżbiety, Don Bernadino de Mendoza został obłożony podejrzeniem o udział w spisku mającym na celu uwolnienie Marii, królowej Szkotów, i wyniesienie jej na tron angielski. Tajna Rada powzięła decyzję o uwięzieniu ambasadora, jednak przed jej wykonaniem zwrócono się o opinię prawną do Gentilisa. Ten, powołując się na prawo rzymskie, stwierdzil, iż immunitet ambasadora jako oficjalnego przedstawiciela obcego państwa wyklucza odpowiedzialność karną. Rada uznając opinię Gentilisa za wiążącą zmieniła swoją decyzję i Mendoza został deportowany".

\footnotetext{
${ }^{8}$ Por. na ten temat P. Stein, Roman Law in European History, Cambridge, 1999, s. 96-97, W. HoldsworTh, $A$ History, cit., s. 52.
} 
W 1587 r. Gentilis objął stanowisko Regius Professor w zakresie prawa rzymskiego w Oxfordzie. W 1605 r. został także adwokatem ${ }^{9}$ przed Sądem Admiralskim, działając na rzecz ambasady hiszpańskiej w Londynie, gdzie ostatecznie zmarł trzy lata później. Warto wspomnieć, iż był gorącym zwolennikiem absolutyzmu. Dzieło De Potestate Regis Absoluta [w:] Regales Disputationes Tres z 1605 r. jest tego wymownym dowodem. Zarzucano mu, już pośmiertnie, iż „nieszczęsne heretyckie zasady”, jakie głosił, posłużyły pierwszym Stuartom do budowy państwa bez Parlamentu ${ }^{10}$. Jeszcze w 1644 r. jego rojalistyczne teorie były przedmiotem złośliwych pamfletów krążących po Parlamencie". Porównywany był do Bodinusa w zakresie sformowanej przez niego teorii absolutyzmu, jak pisze van der Molen, just as Bodin in France, he was the theoretical founder of absolutism in England ${ }^{12}$. Ponadto, położył on znaczące zasługi dla ożywienia kostycznego fakultetu prawa rzymskiego w Oxfordzie, przez tchnięcie new life to the discipline ... określanej obrazowo jako dead body of the civil law written by ancient civilians ${ }^{13}$. Zrozumiały jest zatem w świetle poglądów i wykształcenia Gentilego jego szacunek dla prawa rzymskiego i Korony.

Jako civil lawyer, Gentilis szukał w prawie rzymskim przede wszystkim oparcia ${ }^{14}$ dla budowanej przez siebie doktryny prawa narodów. W kolejnych dziełach próbuje stworzyć podstawy nowej nauki. W De Legationibus opisuje stosunki między państwami w czasie pokoju, w Hispanicae advocationis libri duo podejmuje zagadnienie neutralności, podczas gdy w De Jure Belli próbuje zdefinio-

${ }^{9}$ Por. K. R. Simmond, Alberico Gentili at the Admiralty Bar 1605-1608, "Archiv des Völkerrechts» (1958), s. 3-23.

${ }^{10}$ Por. B. Levack, The Civil Lawyers, cit., s. 4-5.

${ }^{11}$ B. LEVACK, The Civil Lawyers, cit., s. 4

12 G. VAN DER MOLEN, Alberico Gentili and the Development of International Law, Amsterdam, 1938, s. 239.

${ }^{13}$ C. E. MaLlet, A History of the University of Oxford, London, 1924, s. 147.

${ }^{14}$ Por. na ten temat G. DEL VECCHIO, The Posthumous Fate of Alberico Gentili, «The American Journal of International Law» 50 (1966), s. 666. 
wać stan wojny między państwami. Prawo rzymskie stanowi dla niego uniwersalny zwornik pomiędzy cywilizowanymi ludami Europy, który trwa, mimo iż całe państwa przestają istnieć: ius etiam, illis persriptum libris Iustiniani, non civitatis est tantum, sed et gentium, et naturae et aptatum sic est naturam universum, ut imperio extincto, et ipsum ius diu sepultum surrexeri tamen, si in omnes se effuderit gentes humanas $^{15}$. Ponadto, w prawie justyniańskim Gentilis poszukiwał rozwiązań dla konkretnych sytuacji, jakie niosła praktyka międzynarodowa, dla czego przykład opinii w sprawie Mendozy i innych sporządzanych dla Tajnej Rady stanowi wystarczjącą ilustrację.

Richard Zouche urodził się w 1589 r. Ukończywszy studia w Oxfordzie, został przyjęty do Doctors' Commons w 1618 r., aby w następnym roku uzyskać doktorat z prawa rzymskiego (co stanowiło przekroczenie reguł tej organizacji). Już rok później został mianowany regius professor w Oxfordzie. W 1621 r. oraz 1624 r. został wybrany członkiem Parlamentu. Brał czynny udział w życiu akademickim, uczestnicząc w kodyfikacji statutów Uniwersytetu Oxfordzkiego oraz orzekając w uniwersyteckim Court of ViceChancellor. Ponadto był aktywnym praktykiem, a od $1641 \mathrm{r}$. sędzią Sądu Admiralicji. Jako rojalista, w 1649 r. wraz ze śmiercią Karola I został pozbawiony urzędu sędziowskiego, kontynuował jednak karierę uniwersytecką i naukową. Jako jeden $\mathrm{z}$ niewielu civil lawyers, wykładając swoją teorię absolutyzmu zdecydował się na przedstawienie w pięciu punktach „prerogatyw sprawiedliwości” przysługujących angielskiemu monarsze ${ }^{16}$. Uznawany jest za jednego $\mathrm{z}$ ojców współczesnego prawa międzynarodowego. Holdsworth przytacza opinię Wooda, przedstawiającą Zouche'a jako an exact artist, a subtile logician, expert historian, and for the knowledge in and prac-

\footnotetext{
is A. Gentili, De Jure Belli, roz. 5, cytat za B. Levackiem, The Civil Lawyers, cit., s. 99.

is 1 . Władza określania miar i wag. 2. Władza bicia monety. 3. Władza tworzenia magistratur dla wymierzania sprawiedliwości. 4. Autorstwo i interpretacja prawa przy jednoczesnej niezależności od niego. 5. Władza nad życiem i śmiercią wraz z prawem laski. Por. B. LEVACK, The Civil Lawyers, cit., s. 100.
} 
tice of the civil law, the chief person of his time, as his works, much esteemed beyond the seas partly testify ${ }^{17}$. Jak widać, Wood gloryfikuje przede wszystkim znajomość i umiejętność wykorzystania przez Zouche'a prawa rzymskiego. Pozostawil po sobie wiele przeróżnych prac, jak pisze Holdsworth, zadziwiająco wiele jak na człowieka zajętego tak różnymi obowiązkami ${ }^{18}$. Ich tematyka jest bardzo różnorodna: znajdujemy tam zagadnienia dotyczące prawa, religii, wojska, marynarki, stosunków międzynarodowych i wiele innych ${ }^{19}$. Dla prawnika interesujące są Elementa Jurisprudentiae, oparte na rzymskim podziale na status, dominium, debitum, delictum i Judicium, jak również Jus inter Gentes oraz Juris et Judicii Fecialis. Szczególnie Jus inter Gentes nosi znaczące ślady oddziaływania myśli romanistycznej na kształt tworzącego się prawa narodów. Ten traktat o prawie narodów został oparty na wspomnianym podziale według systematyki rzymskiej. Według współczesnej oceny zastosowanie systematyki rzymskiego prawa prywatnego do opisu prawa międzynarodowego nie jest najlepszym rozwiązaniem, świadczy jednak o pozycji, na jakiej stawiał go ów angielski prekursor nauki prawa narodów.

Kolejnym autorem jest Robert Wiseman. Chociaż obecnie nieco zapomniany ${ }^{20}$, niewątpliwie był on pierwszym na świecie autorem traktatu o prawie rzymskim jako podstawie prawa narodów. Tytuł mówi w tym przypadku sam za siebie: The Law of Laws: or, the Excellency of the Civil Law above all other Human Law whatsoever. Shewing of how great use and necessity the Civil Law is to the Nation. Dzieło to, pochodzące z 1656 r., należy wprawdzie do nurtu twórczości prawno-politycznej civil lawyers doby pierwszych Stuartów, zostało jednak napisane już po wojnie cywilnej. Można zatem do-

${ }^{17}$ W. HOLDSWORTH, $A$ History, cit., s. 18.

${ }^{18}$ W. HOLDSWORTH, $A$ History, cit., s. 18.

${ }^{19}$ W. HoldsworTh, $A$ History, cit., s. 18.

${ }^{2 n} \mathrm{~W}$ czasie kwerendy bibliotecznej uzyskałem informację z British Library, iż w Wielkiej Brytanii znajduje się tylko jeden egzemplarz tego dzieła, nie licząc oczywiście bibliotek prywatnych. 
mniemywać, iż nie miało ono charakteru traktatu „na zamówienie polityczne", a zawierało wyraz rzeczywistych i nieskrępowanych poglądów autora. Wiseman rozciągnął autorytet prawa rzymskiego na prawo narodów, wywodząc $z$ niego regulacje dotyczące ambasad, kurtuazyjnego traktowania cudzoziemców, wolności handlu, swobody przekraczania granic, akcji odwetowych, zachowania i wykupywania jeńców itd. Uznaje, że jest to prawo, które można zastosować do wspólnot ludzkich, związku całego rodzaju ludzkiego. Jednocześnie jednak podkreśla, że nie sposób przejąć prawa rzymskiego w całości, szczególnie tej jego okolicznościowej części dotyczącej codziennego życia Rzymian ${ }^{21}$.

Henry Maine, któremu przypisuje się poczesne miejsce w doktrynie prawa międzynarodowego, widział w prawie rzymskim jedno z czołowych źródeł nowej gałęzi prawa, naturalne było również dla niego zastosowanie tego prawa $\mathrm{w}$ praktyce międzypaństwowej. Swoje opinie i poglądy zawarł w International Law z 1894 r., jak również w serii wcześniejszych wykładów w Cambridge (1887 r.), których tematem było prawo międzynarodowe $\mathrm{z}$ obszernym wstępem charakteryzującym sytuację polityczną w Europie. Jedną $\mathrm{Z}$ pierwszych podjętych kwestii była próba wyjaśnienia procesu ewolucji, a przede wszystkim powstania prawa międzynarodowego. Wyjaśnia ten problem, dochodząc do wniosku, że pod wpływem ekspansji prawa rzymskiego w Europie państwa ją tworzące ukształtowały swoje systemy prawne. Dlatego też prawo rzymskie stanowi naturalny składnik prawa międzynarodowego: $A$ great part, then, of International Law is Roman Law, spread over Europe by a process exceedingly like that which, a few centuries earlier, had caused other portions of Roman Law to filter into the interstices of every European legal system ${ }^{22}$. Jednocześnie zaznacza, iż elementem romanistycznym w prawie międzynarodowym są przede wszystkim relikty

${ }^{21}$ R. WISEMAN, The Law of Laws: or, the Excellency of the Civil Law above all other Human Law whatsoever. Shewing of how great use and necessity the Civil Law is to the Nation, London 1656, s. 4-25.

${ }^{22}$ H. S. MAINE, International Law, London, 1894, s. 20. 
jus gentium ${ }^{23}$. Maine wskazuje także na praktykę posługiwania się terminem „prawo naturalne” (natural law) na oznaczenie prawa rzymskiego w państwach nie w pełni uznających jego autorytet. Jako przykład angielski podaje Edwarda III, domagającego się od papieża uznania go za króla Francji, motywując swe prawa do dziedziczenia „prawem naturalnym”, chociaż, jak pisze Maine, dziedziczenie po kądzieli było pure Roman Law of recent origins ${ }^{24}$.

Sir Robert Phillimore, doktor prawa rzymskiego z Oxfordu, członek Tajnej Rady Jej Królewskiej Mości, a także sędzia Sądu Admiralicji pozostawił po sobie wiele dzieł $\mathrm{z}$ zakresu prawa międzynarodowego, pośród których wyróżniają się Commentaries upon International Law z 1879 r. Jest równie entuzjastycznie, jak jego poprzednicy, nastawiony do prawa rzymskiego jako podstawy prawa międzynarodowego: The Roman Law may in truth be said to be the most valuable of all aids to a correct and full knowledge of international jurisprudence, of which it is indeed, historically speaking, the actual basis ${ }^{25}$. Phillimore pozytywnie wyraża się o współczesnym stosowaniu prawa rzymskiego w praktyce międzynarodowej: Roman Law ... is applicable to the controversies of independent States ...26. Jako ilustrację podaje udane przykłady takich zastosowań w sporach pomiędzy USA a Hiszpanią w sprawie żeglugi po Mississippi w 1792 r., regulacji wolności nawigacji po rzekach granicznych i innych $^{2}$. Proponuje także stosowanie prawa rzymskiego w sporach dotyczących licznych kolonii zamorskich ${ }^{28}$. Jego opinia o tym prawie jako czynniku regulacji stosunków międzynarodowych zasługuje w pełni na zacytowanie: And to all nations, whatsoever and wheresoever, this Law presents the unbiassed judgement of the calmest reason,

\footnotetext{
${ }^{23}$ H. S. MAINE, op. cit., s. 20.

${ }^{24}$ H. S. MAINE, op. cit., s. 21.

${ }^{25}$ R. Phillimore, Commentaries upon International Law, London, 1879, s. 32.

${ }^{26}$ R. Phillimore, op. cit., s. 33.

${ }^{27}$ R. Phillimore, op. cit., s. 34.

${ }^{23}$ R. Phillimore, op. cit., s. 34.
} 
tempered by equity, and rendered perfect, humanly speaking, by the most careful and patient industry that has ever been practically applied to the affairs of civilized man ${ }^{29}$.

3. Przechodząc $z$ kolei do praktyki prawa narodów, pragnę przedstawić kilka spraw, w których Wielka Brytania brała udział jako strona, odwołując się do prawa rzymskiego jako argumentu lub kontrargumentu w konkretnym sporze, bądź też takich, w których roszczenia przeciw Wielkiej Brytanii opierało się na prawie rzymskim.

Przykład zastosowania prawa rzymskiego w tym zakresie stanowi w szczególności arbitra $\dot{z}^{30}$ w sprawie Morza Beringa w Paryżu w 1893 r. Jednym z podniesionych przy tej okazji zagadnień była kwestia, czy Stany Zjednoczone mają, a jeśli tak to jakie, prawo do ochrony fok przebywających na wyspach należących do USA na Morzu Beringa, gdy foki te znajdą się poza granicą trzech mil morskich. Przedstawiciel USA udowadnial, iż jego kraj ma prawo do fok, bowiem zostały one poczęte, urodzone i wychowane na przynależnej USA wyspie, uczyniły z niej swój dom, spędzają na niej większość swego życia, a w czasie nieobecności zachowują animus revertendi i nigdy nie zwróciły się ku innej ziemi. Amerykanie posłużyli się tu argumentacją prawa rzymskiego, w myśl którego na zwierzęciu, jeżeli oddali się ono od domostwa, zachowując tzw. nawyk powrotu, nie wygasa prawo własności i nie staje się ono rzeczą niczyją, a zatem nie można go zawłaszczyć3 ${ }^{3}$. Stany Zjednoczone domagały się w konsekwencji uznania, iż analogicznie jak w prawie rzymskim foki wypływające poza strefę trzech mil nie stają się niczyimi i nie można ich jako przedmiotu własności USA odławiać. Arbitraż przekształcił się w teoretyczne dysputy na temat rozumienia rzymskiego pojęcia zwierząt ferae naturae i znaczenia animus

${ }^{29}$ R. Phillimore, op. cit., s. 34.

${ }^{30}$ Przebieg arbitrażu analizuje szczególowo H. LAUTERPACHT, Private Law Sources and Analogies of International Law, Londyn 1927, s. 226.

${ }^{31}$ W. OsuchowsKI, Rzymskie prawo prywatne. Zarys wykladu ${ }^{2}$, Warszawa 1986, s. 266. 
revertendi. Wielka Brytania utrzymywała, iż foki są zwierzętami ferae naturae, i własność na nich, o ile znajdują się poza granicą trzech mil, zależy od aktualnego fizycznego posiadania. W rezultacie Trybunał uznał, iż reguły prawa rzymskiego nie mogą w tym przypadku przeważyć nad ustaloną od dawna w prawie międzynarodowym granicą wód terytorialnych, a także zasadą wolności mórz. Przyznanie USA prawa do fok naruszyłoby natomiast tę zasadę. Takie orzeczenie nie oznacza jednak zanegowania możliwości stosowania reguł prawa rzymskiego w zakresie prawa międzynarodowego, a nawet ją potwierdza. Wskazuje ono jedynie na błędne rozumienie jego pojęć przez jedną ze stron. Przy okazji nie można tutaj nie dostrzec rozszerzającej wykładni rzymskiego pojęcia animus revertendi. Zasada dotycząc sytuacji, w jakiej zwierzęta mogły zostać w pewnych okolicznościach uznane za rzeczy niczyje, niewątpliwie odnosiła się tylko do zwierząt domowych bądź udomowionych, nie można natomiast stosować jej do zwierząt dzikich, które miały status rzeczy niczyich, a zawłaszczenie ich nawet na cudzym terenie łowieckim powodowało pierwotne nabycie własności. Stany Zjednoczone domagały się uznania dzikich przecież fok za swojego rodzaju zwierzęta domowe i z kolei przyznania statusu domostwa skrawkowi swojego terytorium. Ostatecznie odmówiono roszczeniom Stanów Zjednocźonych, uzależniając własność na fokach poza granicą trzech mil od aktualnego fizycznego posiadania. Bezspornym faktem pozostaje jednak tutaj zastosowanie argumentacji $\mathrm{z}$ dziedziny prawa rzymskiego $\mathrm{i}$ jego roli $\mathrm{w}$ rozstrzyganiu współczesnego $\mathrm{w}$ zasadzie sporu między podmiotami prawa międzynarodowego.

Z kolei w sprawie ${ }^{32}$ o ustalenie przebiegu granicy na Alasce między terenami Wielkiej Brytanii i Stanów Zjednoczonych w 1903 r., Wielka Brytania domagała się stosowania zasad dowodowych common law, obcych systemom kontynentalnym, argumentując iż systemy prawne obu stron bazują na prawie anglosaskim. Arbitrzy orzekli

\footnotetext{
${ }^{32}$ Proceedings of the Alaskan Boundary Tribunal, U. S. Senate Documents, Washington 1904, No 162.
} 
jednak, iż procedury dowodowe common law nie mogą mieć zastosowania w sporach międzynarodowych, ponieważ cała struktura prawa międzynarodowego wywodzi się z prawa rzymskiego, które ugruntowało treść kontynentalnych systemów prawnych. Trybunał Arbitrażowy, kierując się procedurami i zasadami dowodowymi o rodowodzie rzymskim, musi więc stosować te zasady, nawet jeśli spór toczą ze sobą wyłącznie państwa systemu anglosaskiego. W orzeczeniu tym wyraźnie zaakcentowano rolę prawa rzymskiego jako źródła prawa międzynarodowego. Należy wspomnieć, iż był to okres intensywnego rozwoju prawa międzynarodowego, przy czym istotny wpływ na nie miały ówczesne mocarstwa o systemach anglosaskich.

Kolejny przykład powoływania się na autorytet prawa rzymskiego stanowi arbitra $\dot{z}^{33} \mathrm{w}$ sprawie rybołówstwa na północnym wybrzeżu Atlantyku z 1910 r.. Stany Zjednoczone utrzymywały, że przyznana im przez traktat z 1818 r. wolność połowów ustanowiła międzynarodową służebność, która uchyliła suwerenność Wielkiej Brytanii, jako państwa służebnego na terenach towieckich. Prawnicy USA dowodzili, iż służebność prawa międzynarodowego ogranicza suwerenność państwa służebnego i stanowi w sposób analogiczny jak w prawie rzymskim, to jest $\mathrm{z}$ wyraźnym odróżnieniem praedium dominans i praedium serviens. Według konstrukcji rzymskiej, argumentowali Amerykanie, służebność gruntowa to prawo domagania się każdorazowego właściciela gruntu panującego (praedium dominans), aby każdorazowy właściciel gruntu służebnego (praedium serviens) znosił jego ingerencję na własnej nieruchomości. W kontekście tej sprawy, trzeba jednak przypomnieć, że prawo rzymskie ściśle określało sposoby powstania służebności gruntowej. Można je było ustanowić ch $^{34}$ przez mancipatio, in iure cessio, legatum per vindicationem oraz adiudicatio. Sposoby ustanowienia służebności były tu enumeratywnie wyliczone, chociaż możliwe było $w$ pewnych okresach zasiedzenie służebności, a walor legalnego ustanowienia

${ }^{33}$ Por. analizę arbitrażu H. LAUTERPACHT, op. cit, s. 239.

${ }^{34}$ Por. W. OsuchowsKI, Rzymskie prawo, cit., s. 289 i n. 
przyznawano też w razie służebności wykonywanych od niepamiętnych czasów. Stany Zjednoczone odniosły tu jednak wątpliwy sukces. Przekonany bowiem o słuszności tych wywodów trybunal arbitrażowy przyjął $w$ całości pogląd o potrzebie zastosowania analogii z prawa rzymskiego, ale jednocześnie zażądał przedstawienia dowodu na to, iż służebność została ustanowiona, czego USA nie mogły oczywiście dokonać. Analiza akt sprawy dowodzi, iż przedstawiciel USA, senator Root, w ostatniej chwili zorientował się dokąd zmierza rozumowanie trybunału i podjął próbę ratowania sytuacji, $\mathrm{z}$ wydatną pomocą amerykańskiego członka trybunału, sędziego Graya. Warto przytoczyć resumé Roota: „Praw nie tworzy się, aby zależały od analogii; one są wyjaśniane przez analogię ... Nie twierdzimy, iż nasze uprawnienia wynikające $z$ traktatu nie mogą być naruszane, ponieważ wypływają $\mathrm{z}$ analogii $\mathrm{z}$ rzymskim prawem służebności. Twierdzimy, iż prawo nasze należy interpretować w świetle tego i podobnych mu praw, w sposób akceptowany długie lata przez narody świata"3s. W końcowej wymianie argumentów sędzia Gray pytał Roota, czy trybunał powinien interpretować pojęcie służebności ściśle według jego technicznej definicji, na co Root odpart, iż istotę tego uprawnienia należy rozumieć tak, jak jest generalnie wyjaśniana, bez wikłania się w techniczną definicję i jej konsekwencje. Niestety, podczas wcześniejszych wystąpień przedstawiciele amerykańscy zdołali skutecznie przekonać trybunał, iż do wyjaśniania istoty pojęcia służebności międzynarodowych należy przyjąć ścisłą analogię z rzymskim prawem służebności wraz z wszystkimi jej następstwami. Konsekwentnie więc trybunał zażądał przed-

\footnotetext{
${ }^{35}$ Argument of the Honourable Elihu Root on behalf of the United States, Washington 1912, s. 250, tlumaczenie autora; por. też H. LAUTERPACHT, op. cit, s. 239: The victory of the American theoretical contention caused its practical defeat. It proved too much. For it was owing to the real and extended rights conferred by an international servitude that the tribunal was prepared to affirm it only on the 'express evidence of international contract'. It did not reject the conception of servitudes, but it demanded a strict proof that a servitude has been created. Such a proof could not be supplied by the United States.
} 
stawienia dowodu zawarcia międzynarodowej umowy służebności, a takiej oczywiście USA z Anglią nie zawierały. Stanom Zjednoczonym odmówiono więc uznania traktatowego prawa połowu za prawo służebności na wodach angielskich. Sprawa ta jest przykładem zastosowania prawa rzymskiego w sporze międzynarodowym per analogiam, później zresztą krytykowanym i rewidowanym. W rzeczywistości problemy sprawiało traktowanie suwerennego państwa jako prywatnego właściciela, uznano także, iż praedium dominans to nie terytorium, a suwerenność państwa władnącego.

Rzadko która sprawa międzynarodowa zawierała natomiast tak liczne odwołania do prawa rzymskiego jak międzynarodowy arbi$\operatorname{traz}^{36}$ z 1903 r. w sprawie żądania przez trzy państwa będące wierzycielami Wenezueli prawa preferencyjnego traktowania. Państwa uczestniczące w sporze, w tym Wielka Brytania, zgodnie uznały iz w spornych kwestiach kierować się będą prawem rzymskim. „Trzy sprzymierzone mocarstwa szukają, tak jak my, uzgodnienia swych żądań na zasadach prawa cywilnego i prawa rzymskiego ius gentium"37. Tak piszą negocjatorzy hiszpańscy o przeciwnikach, ci zaś rewanżują się opinią, iż „Zasadą którą powinniśmy się kierować jest system prawny wyrażony przez ius i lex oraz opinie rzymskich jurystów"38. Państwa żądające preferencyjnego traktowania domagały się uznania, iż ustanowienie dla nich dochodów $\mathrm{z}$ opłat celnych powinno powodować powstanie prawa zastawu i hipoteki w rozumieniu prawa rzymskiego. Istnienie tych praw wiązało się z przywilejem preferencji przysługujących wierzycielowi odnośnie do przedmiotu zastawu lub hipoteki. Co więcej, żądano uznania, iż przyznanie dochodów $\mathrm{z}$ ceł powoduje powstanie specyficznego międzynarodowego ius retentionis przysługującego na wenezuelskich prowincjach La Guiara i Puerto Cabello, a co za tym idzie również możliwość zajęcia tych prowincji i ich blokady morskiej.

${ }^{36}$ The Venezuelan Arbitration before the Hague Tribunal, U. S. Senate Documents, VI, Washington 1903; por. też H. LAUTERPACHT, op. cit, s. 251.

${ }^{37}$ H. LAUTERPaCHT, op. cit., s. 252.

${ }^{38}$ H. LAUTERPACHT, op. cit., s. 252. 
Państwa prowadzące blokadę morską Wenezueli zażądały, aby pozostali uczestnicy sporu partycypowali w jej kosztach, argumentując, iż zachowywały się w stosunku do nich jak rzymski negotionum gestor, czyli prowadzący cudze sprawy bez zlecenia. Należy tu przypomnieć, że zgodnie $\mathrm{z}$ istota $a^{39}$ tego quasi-kontraktu gestor prowadzący cudzą sprawę bez wiedzy i zlecenia dominus negotii mógł się domagać od niego zwrotu nakładów koniecznych i użytecznych, jednak nie wtedy, gdy prowadzit interesy wbrew jego woli, co zostało wyraźnie podkreślone przez kodyfikację justyniańską. Negotiorum gestor był też obowiązany do wynagrodzenia szkody wyrządzonej przez niewłaściwe prowadzenie sprawy. Ponadto wymagano, aby sprawa była prowadzona w interesie dominus negotii (utiliter gestum) ${ }^{40}$. Państwa, od których żądano zwrotu części kosztów blokady w myśl zasad dotyczących negotionum gestio oponowały, twierdząc, iż domniemany gestor działał wręcz na ich szkodę, jako że blokada morska zmniejszyła znacząco możliwości płatnicze morskiej Wenezueli, co należy rozumieć jako wyrządzenie szkody niewłaściwym prowadzeniem sprawy. Ponadto, skoro część państw-wierzycieli nie przyłączyła się do blokady, to należało uznać, iż taka była ich wola, więc a contrario blokada prowadzona była wbrew ich woli.

Kolejna interesująca i szeroko dyskutowaną już w europejskiej doktrynie ${ }^{41}$ sprawa Indian Oil Corp. Ltd v. Greenstone Shipping S.A. jest zupełnie współczesna. W $1987 \mathrm{r}$. na skutek winy przewoźnika ropa naftowa należąca do Indian Oil uległa zmieszaniu z inną przewożoną tankowcem przez Greenstone Shipping. Powstał problem z zakresu prawa rzeczowego, dotyczący własności zmieszanych surowców. Angielskie precedensy pozwalały obciążyć stronę

\footnotetext{
${ }^{39}$ Por. W. Osuchowski, Rzymskie prawo, cit., s. 379 i n.

${ }^{* 0}$ W. Osuchowski, Rzymskie prawo, cit., s. 379 i n.

${ }^{41}$ Por. np. P. SteIn, Indian Oil Corp. Ltd v. Greenstone Shipping S.A., "Cambridge Law Journal» 46 (1987), s. 369 i n.; R. KNÜTEL, Rechtseinheit in Europa und Römisches Recht, "Zeitschrift fur Europäisches Privatrecht» 2.2 (1994), s. 244 i n.; R. Zimmermann, The Law of Obligations: Roman Foundations of the Civilian Tradition, Cape Town 1990.
} 
winną zdarzenia utratą własności na korzyść strony przeciwnej. Sędzia angielskiego sądu polubownego uznal jednak niewłaściwość jakiejkolwiek wcześniejszej sprawy i postanowił zastosować rzymską instytucję confusio - the rule which justice required ${ }^{42}$. W wyniku jej zastosowania uznano, iż na skutek zmieszania doszło do powstania współwłasności - ropa miała zostać podzielona w stosunku do udziału ilościowego obu stron, z zachowaniem prawa do ewentualnych roszczeń o naprawienie szkód, jakie mogły w wyniku tej sytuacji powstać ${ }^{43}$.

4. W rezultacie należy stwierdzić, iż prawo międzynarodowe nosi znaczne ślady wpływów prawa rzymskiego, które należy uznać za istotny element jego struktury historycznej. Jak pokazują wskazane przykłady, zasady i instytucje prawa rzymskiego stanowiły inspirację dla teorii i praktyki prawa międzynarodowego, zarówno dla prawników kontynentalnych jak i anglosaskich. Warto również wskazać na niewątpliwą rolę, jaką prawo to może odegrać w procesie jednoczenia i unifikowania ram przyszłego prawa wspólnej Europy. I chociaż wciąż nie znamy ostatecznego kształtu przyszłego superpaństwa, z pewnością prawo rzymskie zdolne jest wystąpić w roli jego prawnego kręgosłupa.

\section{ROMAN LAW AS A PART OF THE ENGLISH DOCTRINE AND PRACTICE OF THE INTERNATIONAL LAW}

\section{Summary}

This paper presents views on the role played by Roman Law as a factor in creating the roots of international law which developed within the English legal doctrine from the $16^{\text {th }}$ to the $19^{\text {th }}$ century. In addition, it exemplifies applications of the institutions of Roman law in international legal

${ }^{\prime 2}$ Por. P. Stein, Roman Law in European History, Cambridge, 1999, s. 128.

${ }^{43}$ Por. I. 2,1,27. 
practice. The general theory discounts the influence of Roman law on the British system of law. This, however, should be reviewed, as the evidence shows that Roman law has always played a vital role in the English legal system (e. g. Courts of Chancery, Admiralty, Constable and Marshall, Ecclesiastical Courts, Doctors' Commons organisation). The Roman influences on the doctrine of English international law (Gentilis, Zouche, Duck, Wiseman, Westlake, Maine, Phillimore) indicate a positive, or even enthusiastic attitude towards the use of Roman law as a source of international law. One of the public branches where English practitioners and theorists of civil law could always find employment was in HM Foreign Service, which had a strong need for lawyers qualified in Roman law who were often educated and trained at English universities.

One of the earliest authors describing the use of the theory and practice of Roman law in international law was Alberigo Gentili. Although he was Italian, his professional life and career was bound to England as both a Regius Professor at Oxford University and as a legal counsellor for the Privy Council. He gained much prominence and his works on international law, De Jure Belli, De Legationibus and Advocationis Hispanicae have become frequently quoted in the theory of international law. Another Oxford Regius Professor, and a judge in the Admiralty Court, Sir Richard Zouche, together with Gentili and Grotius, is regarded as the father of international law. Among his many works, Jus inter Gentes and Juris et Judicii Fecialis illustrate the influences of Roman law on the developing theory (and practice) of international law. The Roman ideas are particularly visible in Jus Inter Gentes, where Zouche had used the Roman systematic of status, dominium, delictum and judicium to classify and explain international law theory. Another $17^{\text {th }}$ century civil lawyer, Sir Robert Wiseman, in The Excellency of the Civil Law above all other Human Law glorifies the Roman law as universal law for all nations, applicable to many international debates. One of the most famous British civilians and international law experts, Sir Henry Maine considered the Roman law as an important resource and element of the 19th century doctrine of international law. According to Sir Robert Phillimore, the Roman law could be used in the controversies between independent States. As an example he described the cases between the USA and Spain concerning navigation in the Mississipi 
River, boundary disputes and arbitration. He proposed application of the Roman law to numerous cases concerning overseas properties.

Apart from theory, hundreds of international cases bear traces of successful application of the Roman law to resolve situations when there was no actual law institution to bridge the legal divide. This paper presents five international cases in which an important role was played by Roman law. Arbitration of the Behring Sea dispute in 1893, where the UK and the USA argued about the UK's right to hunt seals outside the three miles boundary area of the Pribilofs Isles. Both sides used arguments based on Roman law. The Americans view was that seals born on the isles would always return to the shore, not losing animus revertendi of Roman law, thus not becoming res nullius and not subject to "occupation" by the UK fishermen. The British delegates claimed that the seals were born ferae naturae (another Roman law category), and so everyone should be entitled to hunt them.

The Alaskan Boundary Tribunal proceedings of 1903 declared that Roman law rules, as a source of international law, should take precedence over the rules of common law.

During the Venezuelan arbitration before the Hague Tribunal in 1903, the opponents dealt with many Roman law institutes (like pignus, hypotheca, cessio bonorum, negotiorum gestio and others), trying to adjust them to their actual position.

In 1910 the Arbitration Tribunal concerning fishing on the North Atlantic coast allowed the Roman definition of servitude and attempted to treat a state's territory as a Roman property.

The last case dealt with in the paper is the famous Indian Oil Corp. Ltd $v$. Greenstone Shipping dispute of 1987. The British judge applied the Roman law of confusio, declaring that no previous common law precedent was applicable to this case in which crude oil had been accidentally mixed on board the tanker.

Taking into consideration these examples, one may draw the conclusion that Roman law has been an inspiration for European lawyers, as well as English common lawyers, in both the theory and practice of international law. 